\title{
モーダルシフトの整数計画モデル
}

三木 楯彦 $*$ 山内内 悟 ${ }^{* *} \cdot$ 新谷 浩一 $*$

\section{An Integer Programming Model for Modal Shift}

\author{
Tatehiko MIKI, Satoru YAMAUCHI and Koichi SHINTANI
}

\begin{abstract}
The problem authors consider is that of preparing a minimum cost transportation plan for modal shift associated with the milk transportation between Hokkaido and Tokyo.

In this paper, we present a solution method for this problem using an integer programming model with linear objective functions subject to all feasible traffic flows and all the combinations of constructing different candidate links. In order to illustrate the model, results are presented for modal shift with multiple mode of transportation including RORO ships, ferries, rail and milktank lorries.
\end{abstract}

\section{1.はじめに}

物流効率化の手段として長距離幹線輸送において自動車から鉄道輸送へ、あるいは海運への輸送機関を 転換する方策をモーダルシフトと呼んでいる。近年の多頻度小口配送の要請にも応えつつ海運、特に長距 離フェリーとトラックの複合輸送が重要視される。

トラックによる貨物輸送数量が国内物流に占める割合は、輸送トン数ベースで $90 \%$ 、トンキロベース で約 $50 \%$ である。他方、内航海運はトン数べースで $9 \%$ 、トンキロベースで $45 \%$ である。この数字は長距 離大量輸送では船舶が、近距離輸送にはトラックが利用されていることの証明である。

近年、トラック業界ではドライバー不足, 交通泳滞, 法定労働時間の短縮, 環境污染の悪化などで対応 策に苦慮している。鉄道輸送をみると、速度, 環境污染はトラックに比し格段によく長距離輸送に向くが、 旅客輸送ダイヤが過密で、新規線路の設備投資も短期的には難しく今後の伸びは期待できない。

こうして見直されてきたのが内航海運で、運輸省も率先して陸上物流を海上に振り向ける政策を振興し ている。RORO 船やフェリーは、大量輸送, 省エネ, ドライバーや港湾荷役作業員の人手不足解消, 環境 污染の軽減などの観点からモーダルシフトの焦点にある。

わが国の高度成長時代は人手不足による人件費の上昇の時期でもあり、輸送革新が叫ばれた。海運界で 6荷役革新船が登場し、(1)リフトオン・リフトオフ方式のコンテナ船, (2) ロールオン・ロールオフ船, (3) 旅客カーフェリーは革新船の三羽烏と言えよう。そのうち (1) のコンテナ船は当初、外航海運で発展し たが内航においても現在コンテナ船 11 隻、外航コンテナのフィーダー輸送を含めれば 30 隻を越す内航コ ンテナ船が就船している。(2) は外航海運 (豪州航路) だけでなく内航船では全国に 33 航路の定期幹線があ る。(3)の旅客カーフェリーは内航を主体に就航しているが、旅客用居住区を除けばロールオン・ロールオ フ船と変わらない荷役方式である。即ち、旅客カーフェリーは、トラック，コンテナ積載トレーラが車両 ごと船内に走り込めること、トラック運転手が船に一緒に乗れること、船社にとっては積揚荷役が人手を 要しないこと(機械荷役と同然)、外航コンテナ船で運ばれてきたコンテナをトレーラごと主要港から地 方港へフィーダー輸送ができることが理由で急進展した。

* 正会員 神戸商船大学 (广658 神戸市東灘区深江南町 5-1-1)

**正会員 阪神油化侏( 650 神戸市中央区播磨町 49) 
旅客カーフェリーとロールオン・ロールオフ船と の比較対照すると次のようになる。

モーダルシフトの検討は単に運賃の比較だけでは 結論は得られない。特に新しい輸送路の開発には大 なり小なり資本投資を伴う。例えば港湾などでの物 流基地や倉庫の新設、コンテナやパレット等のリー ス、荷役機械や特殊車両の開発ないし採用等はほん の一例である。従って、一定期間の固定費及び变動 費を合算した総経費により判断することが不可欠と なる。ネットワーク問題を線形計画法で表現したと き、目的関数に含まれる係数は常数でなければなら ないから一般にリンクの流量に比例する費用（変動

費)のみをモデル中に取り入れることができるに過ぎない。著者らは線形計画法の一類型である輸送問題 に整数変数を付加することによりそのリンクを使用する時に限って発生する固定費を考慮し得る数理計画 モデルを提案し、事例を添え報告する。

\section{2. 輸送経路の決定モデル}

モーダルシフトは運貨のほか、納期や輸送容量などの輸送サービスに支配されていることは周知の事実 である。しかし、コストは第一義的に重要な選択要因であることに変わりはない。そこで、モーダルシフ トの選好原理を表すモデル的研究を行った。モデルは、輸送問題をべースにした整数計画モデルである。 このモデルはネットワークデザイン問題 (NDP, Network Design Problem ) ${ }^{(1)}$ の一類型で、与えられた基 準により既存の輸送ネットワークにおいて枝を付加, 除去, 改善する問題を扱う。定式化の形態は極めて 多様で、目的関数が線形のもの、目的関数が非線形でシステム最適化基準を満たすすの、目的関数が非線 形で利用者最適化基準を満たすすの、等に大別できる。筆者らは次のような定式化を行ったので提案する。 即占、

ネットワーク $[N ; L]$ に対して、

ノード: $i=1,2, \ldots, n$

$i=1:$ 発地

$i=n:$ 着地

$(i, j):$ リンク

$x$ : リンクフロー、 $m \times 1$ リンクフローベクトル

$x_{i j}: x$ の元で、実数变数

$C:$ 目的関数

$f:$ 運賃行列

$f_{i j}$ : 第 1 項の運貨行列 $f$ の元、フローコスト $(m \times 1$ 列ベクトル $)$

$p$ : 投資費用行列

$p_{i j}$ : 第 2 項の投資費用行列 $p$ の元

$y$ : リンクの選択ベクトル

$y_{i j}: y$ の元で、整数変数 $(0-1$ 変数 $)$

$E: n \times m$ ノードリンク連結行列

$g: n \times 1 \quad O-D$ フローベクトル

$g_{i}: g$ の元で、フロー值

$R$ : 輸送路の代替案を表す $n \times m$ 行列

$q: n \times 1$ 整数制約式の定数べクトル

$q_{i}: q$ の元で、 $0-1$ 変数

$M: x_{i j}>0$ であれば $y_{i j}=1$ となるような技巧的制約 $(m \times m$ 行列 $)$ 
ここで、全角文字は行列または列べクトル、半角文字はスカラー変数とする。

このとき主題の定式化は、整数変数を含む輸送問題をべースとするモデルとして次のように表現できる。 (式 1 )

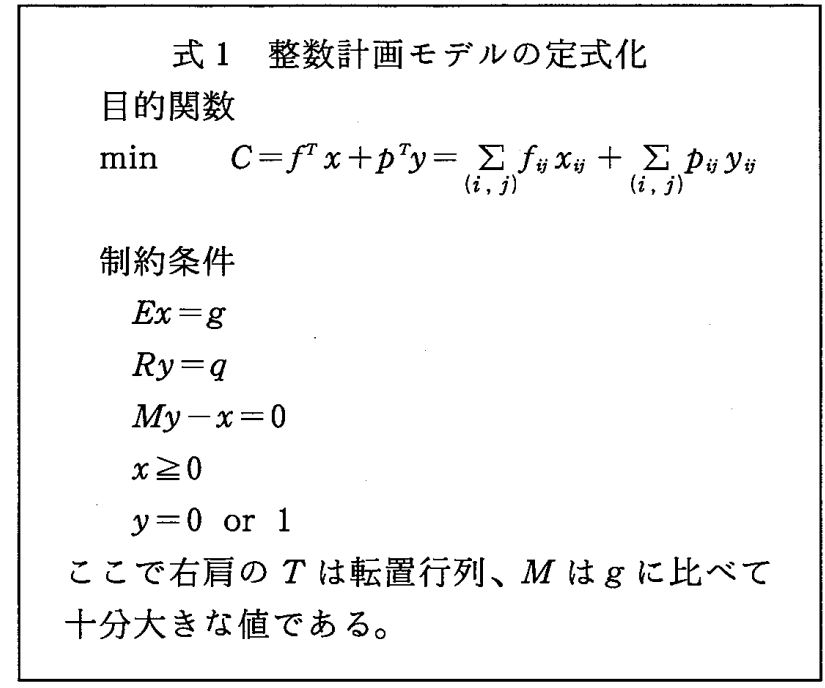

ここで、目的関数の第 1 項は変動費の合計、第 2 項は固定費の合計を表す。制約条件の 1 はネットワーク の構造、2 2 はンク (輸送路) の代替案の選択、輸送路に貨物が流れる時 $\left(x_{i j}>0\right)$ には必ず当該輸送路の 選択を示す選択べクトルが 1 を採る $\left(y_{i j}=1\right)$ となることを要請する制約式である。变数 $x_{i j}$ は正の実数、 $y_{i j}$ は $0-1$ の整数変数である。

\section{3. 事例的研究}

モーダルシフトの対象貨物は「雑貨」である。雑貨とは特に定説はないが、包装または梱包された貨物 及びこれに準ずるものというのが極めて大まかな定義となろう。モーダルシフトの対象とされる貨物とい うことになれば、「ばら荷」，長尺物，液体は除外され、標準 8 トン車に搭載可能な貨物とある程度局限 されてくる。そうなると食料品は国民生活からあ重要な雑貨である。食料品、特に生鮮食料品の輸送はそ の貨物の性状からあ他の輸送機関の利用は制約があり、専らトラックに依存してきたためモーダルシフト の成功例は少ない。

温度管理が必要な商品あるいは生鮮食料品には数例を挙げれば次のようになる。
(1) 生乳
釧路 $\rightarrow$ 東京
保冷タンク車
(2) ミカン
熊本 $\rightarrow$ 関西 / 関東
トラック
勝浦 $\rightarrow$ 関東
コンテナ

(3) アイスクリーム 北海道 $\rightarrow$ 関西 / 関東

冷凍 / 冷蔵

(4) 翰入チーズ 苫小牧 $\rightarrow$ 川崎

コンテナ

(5) 活魚

熊本 $\rightarrow$ 関西

特殊コンテナ

ここでは農畜産物輸送の海運への転換事例として生乳を取り上げる。生乳の生産は 4 月 6 月゙ピークで、 夏場の牛乳の需要期とも一致する。さらに、腐敗し易い性質のため摄氏 4 度内外の低温輸送が必要である。 北海道から本土向けの生乳移出量は年間 27 万トン (平成 3 年実績 )を越え増加傾向にある。仕向地は大部 分が東京地域で、将来輸送方式の開発次第で近畿圏への需要増大も見込まれる。

上記の需要に対し、北海道から関東地域に至る輸送供給力は、JR 貨物のほか長距離フェリ一輸送があ る。生乳の輸送手段はフェリーが $72 \%$ 、JR 貨物が $28 \%$ の両者で大部分を占め、93 年 7 月生乳専用 $\mathrm{RORO}$ 船が投入された ${ }^{(2)}$ 。フェリ一航路は、苫小牧/釧路 $\rightarrow$ 東京，小樽 $\rightarrow$ 新潟，苫小牧/室蘭 $\rightarrow 大$ 洗の 5 航路がある。両地が津軽海峡で隔てられていること、北海道から関東への輸送が翌日配送が困難であるこ と、無人車の普及で省力化の効果が大きいこと等の理由により海運が有利な区間として知られる。モーダ ルシフトの見地から新しい輸送路には各種の投資が必要とされる。フェリーや RORO 船の利用には低温 
輸送の予冷基地、コンテナ船にはミルクタンクコンテナ(冷蔵設備付, 17 トン積)、陸上輸送には冷蔵車 両の取得などがある。こうした固定費は先述の整数変数 $y$ 等の係数として与えることで容易にモデル化で きる。輸送ネットワークの構造を図 1 に、輸送路を要約したものが図 2 に、輸送路の変動費を表 2 に掲げ る。

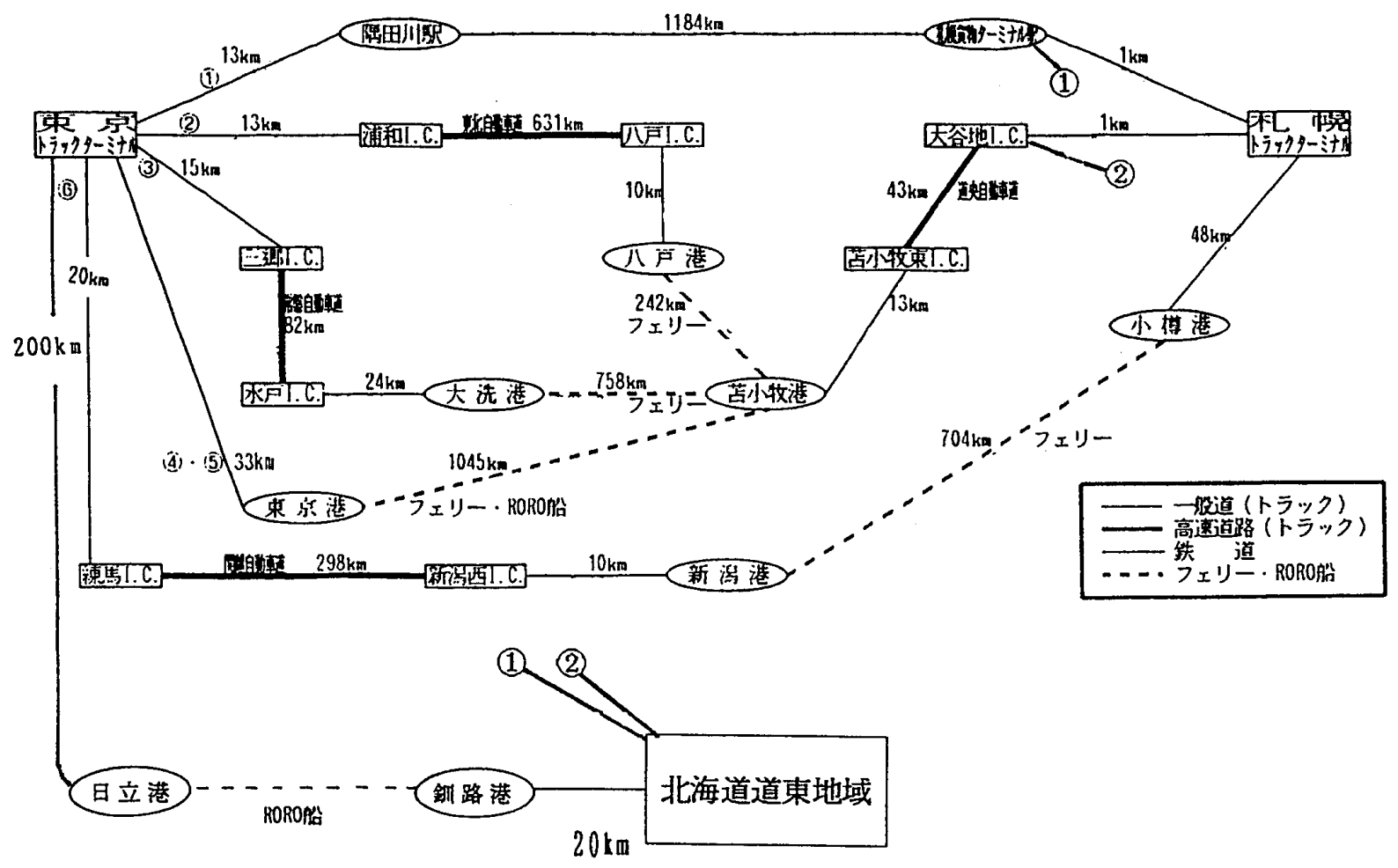

図 1 北海道から東京都に至る輸送ネットワーク

表 2 北海道加ら東京都に至る

輸送経路と変動費

\begin{tabular}{|c|c|c|c|}
\hline \multicolumn{2}{|c|}{ 金送方式 } & 主な徐送経路 & 以当たり遇夏 \\
\hline \multicolumn{2}{|c|}{ (1) 5トンコンテナ； J R候物 } & 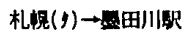 & $16.320 \mathrm{M} / \mathrm{ry}$ \\
\hline \multicolumn{2}{|c|}{ (2) 207 0フトコンテナ；内航コンテナ船 } & 苫小牧港一果京港 & 10.170 \\
\hline (d) 15 & トレーラ：内航RORO粕 & 苫小牧渄一東京港 & 12,840 \\
\hline (4) 15 & トレーラ；フェリー利用 (無人) & 苫小收港一果京港 & 13,550 \\
\hline (5) 10 & トラック：フェリー利用（有人） & 苫小收港 $\rightarrow$ 東京港 & 19.470 \\
\hline (6) 15 & トレーラ；フェリー利用 (無人) & 苫小牧港 $\rightarrow$ 大洗港 & 13,800 \\
\hline (1) 10 & トラック：フェリー利用（有人） & 苫小牧港－大洗港 & 19.240 \\
\hline (B) 10 & トラック：陸上走行 & 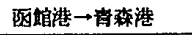 & 24,600 \\
\hline
\end{tabular}

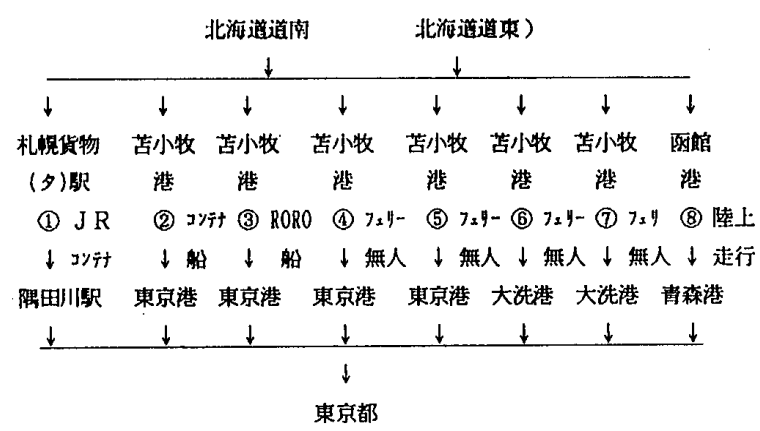

図 2 北海道から東京都に至る輸送経路 (一部)

計算結果から苫小牧港 $\rightarrow$ 東京航路のコンテナ船が最適となった。しかし、陸上輸送や長距離フェリーの 利用には保冷・冷凍トラックへの投資、17トン積みのミルクタンクコンテナ(保冷型)，フェリーによる

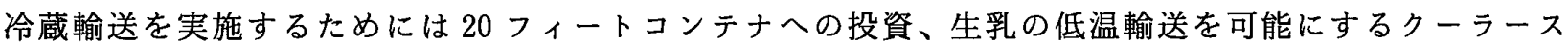
テーション等がある。従って、輸送路に固定費を必要とする場合、容易に変動費だけの結論を覆すに足る 金額である。冷蔵用電源設備のための追加投資を要すれば、フェリ一輸送より予冷基地の投資を含む RORO 船輸送が有利となるなら゙、固定費算入により結論が微妙に影響されることが分かった (表 3 )。

整数計画モデルの一例を下記に示しておく(式 2)。 
式 2. 定式化の例

$\bigcirc$ 目的関数

$$
\begin{aligned}
15 x_{1} & +15 x_{4}+95 x_{5}+57 x_{6}+135 x_{7}+120 x_{8}+55 x_{9}+120 x_{10}+55 x_{11}+120 x_{12} \\
& +70 x_{13}+30 x_{14}+35 x_{15}+31 y_{2}+25 y_{4}+70 y_{11}+30 y_{12}+35 y_{13}
\end{aligned}
$$

○制約条件

$$
\begin{aligned}
& x_{1}+x_{2}=750 \\
& x_{3}+x_{4}=650 \\
& x_{5}+x_{8}+x_{11}=700 \\
& x_{6}+x_{9}+x_{12}=400 \\
& x_{7}+x_{10}+x_{13}=300 \\
& x_{1}-x_{5}-x_{6}-x_{7}=0 \\
& x_{3}-x_{8}-x_{9}-x_{10}=0 \\
& x_{2}+x_{4}-x_{11}-x_{12}-x_{13}=0 \\
& y_{1}+y_{2}=1 \\
& y_{3}+y_{4}=1
\end{aligned}
$$

\begin{tabular}{|c|c|c|c|c|}
\hline 順位 & 輸送方式 & 揚地 & 固定費 ${ }^{1)}$ & 備考 \\
\hline 1 & コンテナ船 & 東京 & 6.55 億円 & クーラーステーション、シャーシ、コンテナ \\
\hline 2 & R O R O船 & 日立 & 5.4 & クーラーステーション、タンクコンテナ \\
\hline 3 & フェリー(無人車) & 東京 & 6.6 & クーラーステーション、タンクコンテナ \\
\hline 4 & フェリー (無人車) & 大洗 & 6.6 & クーラーステーション、タンクコンテナ \\
\hline 5 & 陸上輸送 & - & 5.4 & クーラーステーション、タンクコンテナ \\
\hline
\end{tabular}

$$
\begin{aligned}
& 5000 y_{1}-x_{1}=0 \\
& 5000 y_{2}-x_{2}=0 \\
& 5000 y_{3}-x_{3}=0 \\
& 5000 y_{4}-x_{4}=0 \\
& 5000 y_{5}-x_{5}=0 \\
& 5000 y_{6}-x_{6}=0 \\
& 5000 y_{7}-x_{7}=0 \\
& 5000 y_{8}-x_{8}=0 \\
& 5000 y_{9}-x_{9}=0 \\
& 5000 y_{10}-x_{10}=0 \\
& 5000 y_{11}-x_{11}=0 \\
& 5000 y_{12}-x_{12}=0 \\
& 5000 y_{13}-x_{13}=0
\end{aligned}
$$

\section{表 3 いくつかの条件下での最適解}

注 1) クーラーステーション(耐用年数 15 年、30 億円)、シャーシ(䅡用年数 4 年、60台、 2 セット、0.75 億円)、コンテナ(耐用年数 7 年、 150 台、 4 セット、 4 億円)、タンクコンテナ テナ(耐用年数 6 年 120 台、3セット、3.6 億円)等をそれぞれ年間経費に換算した。

ここで、

$$
x_{i} \ldots \text { 実数変数 }(i=1,2,
$$$$
y_{j} \ldots \text { 整数变数 }(0-1 \text { 変数 })(j=1,2 \text {, }
$$

である。また、この定式化で想定している輸送ネットワークは図 3 のとおりである(図 3 )。

\section{4. 結 論}

このモデルは輸送問題に整数変数を付加することによりそのリン クを使用する時に限って発生する固定費を考慮し得る数学モデルで ある。モーダルシフトの諸問題は新しい輸送路を開設ないし利用す るに当たって多かれ少なかれ固定費を伴う。そのような形式の問題 の解法として有用であることを事例研究として示した。センターコ ストなどのモーダルシフトのための投資金額の変化による感度分析 による微妙な転換の条件が計算可能である。物流問題は決して運賃 のみで決まるあのではなく、荷主は複数の輸送路を等分に利用する など戦略上の解む要請されるが、この解法では最適解しか与えない。 こうした荷主企業の多元的な輸送サービスの選好への拡張も今後の 課題の 1 つである。
仕出し港

港 1 港 2

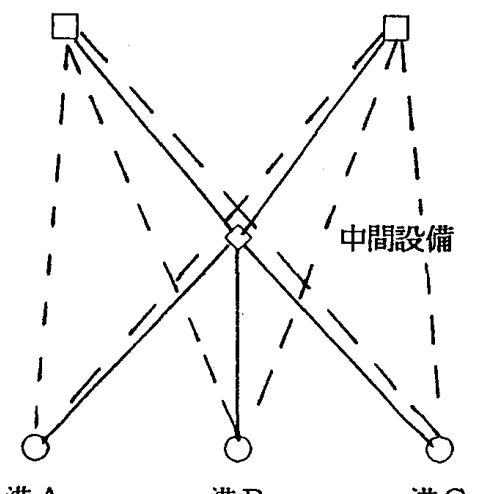

港 $\mathrm{A}$

港 $\mathrm{B}$

港C

仕出し港

図 3 式 2 の輸送ネットワーク 


\section{参 考 文 献}

(1) Mingyuan Chen and Attahiru Sule Alfa : A Network Design Algorithm Using a Stochastic Incremental Traffic Assignment Approach, Transportation Science (ORSA), Vol.25, No.3, August 1991.

（2）原 勝：北海道農業とほくれん丸の就航，物流情報，40 巻 10 号，21-26, 1993.10 .

\section{質 疑 応 答}

今井昭夫 (神戸商船大学)：1) モーダルシフトではコストだけでなく時間が大きなファクターとなると思 われますが、時間を本モデルに組み込むことは可能でしょうか。

2) ケーススタディーでは生産地と消費地が 1 箇所ずつのようですが、あしそうであれば、本モデルは最 短路問題で解けるのではないでしょうか。

三木楯彦：時間や輸送路の容量はモーダルシフト問題で考慮すべき重要な要素です。今回のモデルでは考 察していませんが、1 法として次のような取扱いが可能ではないかと考えます。A 船 (長距離フェリー, 船速 23.5 ノット, 船価 40 億円, 航海時間 20 時間, トン当たり運賃 $x x$ 円), B 船 (RORO 船, 船速 20.0 ノット, 船価 24 億円, 航海時間 32 時間, トン当たり運賃 $y y$ 円) といった投入船舶の代替案を列 挙して納期に合致したルートを選択する場合に整数变数を 1 、選択しない場合に 0 とするように定式化 する、等です。この点については今後検討してみたいと思います。

2)この事例では北海道の道東と道南両地域に分散する酪農家からの生乳が小樽, 苫小牧, 釧路経由の海 路と JR 貨物、さらに道路利用で本州に持ち込まれ、東京を仕向地とする輸送を対象にしています。 従って、本質的には図 3 ないし同図で港 $\mathrm{A}$ と港 $\mathrm{C}$ を除去したモデル構造を持っています。そのため簡 単ではあるが最短路問題では解けない形式だと考えられます。 